\title{
ДИФЕРЕНЦАЛЬНИЙ ПІСИЛЮВАЧ ЕЛЕКТРИЧНОГО СИГНАЛУ НА ЧАСТОТАХ МОВНОГО ДІАПАЗОНУ ДЛЯ ВИЯВЛЕННЯ АКУСТОЕЛЕКТРИЧНИХ ПЕРЕТВОРЮВАЧІВ
}

Робота присвячена актуальним питанням визначення та виявлення електричних каналів витоку інформації за рахунок акустоелектричних перетворювачів, а також вимірювання рівнів сигналів в цих каналах. Робота пов'язана з експериментальними дослідженнями і практичними розрахунками.

У статті наведені характеристики розробленого пристрою, які забезпечують необхідні параметри для дослідження і вимірювання акустоелектричних ефектів в мовному діапазоні частот від різної електронної апаратури. Крім того, даний пристрій може бути використано для постановки і модернізації лабораторних робіт у навчальному процесі. Це дозволить позбутися від дорогого пошукового комплексу «Піранья» в лабораторному циклі дослідження акустоелектричних перетворювачів.

Вступ. Людська мова $\epsilon$ природним i найбільш поширеним способом обміну інформацією між людьми, і існує багато методів перехоплення або підслуховування цієї інформації. Звуком називаються механічні коливання в пружних середовищах і тілах (твердих, рідких і газоподібних), частоти яких лежать в межах від 17-20 Гц до 20000 Гц. Ці частоти механічних коливань здатне сприймати людське вухо. Механічні коливання нижче 17 Гц називають інфразвуками, а понад 20000 Гц - ультразвуками. Акустичний тиск, що виникає під час розмови, може викликати механічні коливання елементів електронної апаратури, що у свою чергу, приводить до появи електричних струмів, напруги i електромагнітних випромінювань або їх змін при певних обставинах [1].

Постановка проблеми. Конфіденціальна інформація, яку містять в собі мовні повідомлення, викликає зацікавленість у конкурентів або зловмисників в здобутті подібної інформації. Враховуючи особливості розташування більшості офісів комерційних підприємств в житлових будинках, розмежованих конструкціями 3 недостатнім акустичним захистом, завдання захисту конфіденційних переговорів стає особливо актуальним і досить складним [2].

Оцінюючи можливості захисту конфіденційних переговорів у приміщенні, доцільно передбачити можливість використання зловмисником елементів апаратури, що мають в собі акустоелектричний ефект - ланцюги дзвінків телефонних апаратів, вторинний годинник, динаміки мереж трансляції, деякі сповіщувачі систем охоронної і пожежної сигналізації і тому подібне [3]. Акустичні перетворювачі можуть бути наступних видів: індуктивні; ємкісні; п'єзоелектричні; оптичні.

В основному витік небезпечних акустичних сигналів здійснюється через допоміжні технічні засоби і системи. Допоміжні технічні засоби і системи, що знаходяться в зоні дії небезпечних акустичних сигналів, не рідко є причиною витоку конфіденціальної інформації за межі контрольованої зони. Сигнали в ланцюгах допоміжних технічних систем і засобів, обумовлені дією зовнішніх акустичних полів, можуть бути вельми значними і перевищувати гранично допустимі для цих ланцюгів величини. До допоміжних технічних систем і засобів відносяться: системи відкритого телефонного зв'язку; системи радіотрансляції; системи електроживлення; системи охоронної і пожежної сигналізації.

Канали витоку інформації, що виникають за рахунок наявності перетворювальних акустоелектричних елементів в ланцюгах різних технічних пристроїв небезпечні тим, що вони можуть існувати в їх нормальних режимах роботи, тобто зловмисник може скористатися ними без проникнення в приміщення або зону, що охороняється, і без встановлення спеціальних закладних пристроїв. Добре відомі методи отримання акустичної інформації з приміщень за рахунок підключення до ліній телефонних апаратів (особливо у випадках, коли в приміщенні розташовані апарати з електромеханічними дзвінками), лініями диспетчерської або охоронної сигналізації і тому подібне. Наприклад, за рахунок 
акустоелектричних перетворень в схемах ланцюга дзвінка, телефонному, мікрофонному капсулях і т.д. виникають інформаційні (небезпечні) сигнали. При покладеній трубці телефонний i мікрофонний капсулі гальванічно відключені від телефонної лінії, та інформаційні сигнали виникають в елементах тільки ланцюга дзвінка. Амплітуда цих небезпечних сигналів не перевищує одиниць мВ. Перехоплення виникаючих в елементах ланцюга дзвінка інформаційних сигналів можливе шляхом гальванічного підключення до телефонної лінії спеціальних високочутливих низькочастотних підсилювачів [4].

Таким чином, значна кількість елементів різних пристроїв, що використовуються в практичній діяльності, володіють акустоперетворювальним ефектом, отже, можуть бути джерелом для створення каналу витоку конфіденційної акустичної інформації. Можливий перелік таких елементів наведено в табл. 1:

Перелік акустоперетворювальних елементів різних пристроїв

\begin{tabular}{|c|c|c|c|c|}
\hline $\begin{array}{l}\text { Електро- } \\
\text { динамічні }\end{array}$ & Електромагнітні & $\begin{array}{l}\text { Електро- } \\
\text { статичні }\end{array}$ & П’єзоелектричні & $\begin{array}{l}\text { Магніто- } \\
\text { стрикційні }\end{array}$ \\
\hline $\begin{array}{l}\text { Електро- } \\
\text { динамічний } \\
\text { гучномовець }\end{array}$ & $\begin{array}{l}\text { Електричні } \\
\text { дзвінки }\end{array}$ & Конденсатори & П'єзодатчики & Фільтри \\
\hline $\begin{array}{l}\text { Електро- } \\
\text { динамічний } \\
\text { мікрофон }\end{array}$ & $\begin{array}{l}\text { Дзвінкові } \\
\text { ланцюги } \\
\text { телефону }\end{array}$ & Реле дроту & Кварцеві вібратори & Резонатори \\
\hline $\begin{array}{l}\text { Котушечні, } \\
\text { стрічкові, } \\
\text { Електродинамічні } \\
\text { вимірювальні } \\
\text { прилади }\end{array}$ & $\begin{array}{l}\text { Вторинний } \\
\text { електрогодинник, } \\
\text { Електромагнітний } \\
\text { мікрофон, } \\
\text { Електромагнітні } \\
\text { вимірювальні } \\
\text { прилади }\end{array}$ & $\begin{array}{l}\text { Плати, } \\
\text { Мікрофони } \\
\text { конденсаторні } \\
\text { електретні }\end{array}$ & $\begin{array}{l}\text { Напівпровідниковий } \\
\text { мікрофон, } \\
\text { П'єзоелектричний } \\
\text { мікрофон, Датчики } \\
\text { зворотнього зв’язку }\end{array}$ & $\begin{array}{l}\text { Елементи } \\
\text { акустоелектроніки, } \\
\text { акустомеханічні } \\
\text { перетворювачі }\end{array}$ \\
\hline
\end{tabular}

Порівняння різних типів акустоелектричних перетворювачів показує, що деякі з них по чутливості близькі до спеціально створених для перетворення звукової енергії в електричну - тобто до мікрофонів. Так, наприклад, чутливість деяких дзвінкових кіл телефонних апаратів досягає 0,05-10 мВ/Па, трансформатора складає 10-200 мкВ/Па, електричного годинника, в залежності від марки, коливається в межах від 100 до 500 мкВ/Па і навіть електричного вентилятора в режимі малих обертів - 10-100 мкВ/Па [5].

Мета роботи. Враховуючи чутливість можливих джерел витоку інформації, необхідно розробити пристрій для дослідження сигналів, що утворюються на акустоелектричних перетворювачах. Важливим завданням $€$ отримання рівнів сигналу з акустоелектричних перетворювачів (таких як реле, динамік та дзвінковий ланцюг телефонного апарату) достатніх для оцінки можливості витоку інформації по електричному каналу і розробити підсилювач, що може використовуватись, як компактна заміна диференціального підсилювача «Піранья».

Основна частина. 3 метою дослідження сигналів, що надходять 3 акустоелектричних перетворювачів було розраховано і створено електронний пристрій, що забезпечує: підсилення електричного сигналу з частотою 250-4000 Гц, який формується на різних типах перетворювачів (а саме реле, динаміку і телефонному апараті); максимальне зменшення рівня шуму, завад і наведень на виході пристрою, за рахунок симетричного входу і смугових фільтрів.

Розроблений пристрій має коефіцієнт підсилення приблизно рівний 18000 на частотах 1-1,5 кГц і значно зменшує рівень шумів і завад, за рахунок симетричного входу і смугових фільтрів. Повністю розраховано і підібрано номінали всіх елементів кожного каскаду підсилювального пристрою, а саме: двостороннього діодного обмежувача, диференціального підсилювача на операційному підсилювачі (ОП), першого активного полосового фільтра на 
ОП, другого активного полосового фільтра на ОП, інвертуючого підсилювача на ОП, фільтруючої системи блока живлення. Структурну схему пристрою представлено у додатку А, електричну принципову схему пристрою - у додатку Б, перелік елементів - у додатку В, зовнішній вигляд пристрою - у додатку Г.

Диференціальний підсилювач - електронний підсилювач 3 симетричним входом, вихідний сигнал якого дорівнює різниці вхідної напруги, помноженій на константу. Використовуючи схему диференціального підсилювача на базі одного операційного підсилювача КР140УД708. При цьому коефіцієнт підсилення схеми буде мати значення:

$$
K=R 3 / R 1=100
$$

Електричну схему диференціального підсилювача представлено на рис. 1.

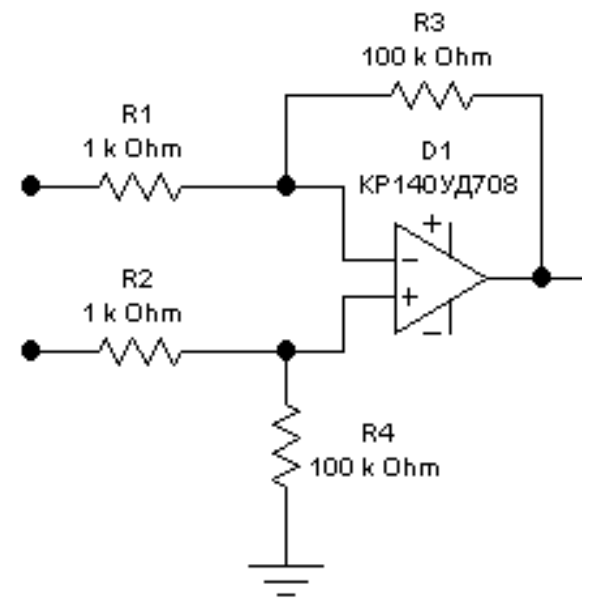

Рис. 1. Електрична схема диференціального підсилювача

В схемі для отримання високого значення коефіцієнту послаблення синфазного сигналу (КПСС) необхідно забезпечити точне узгодження резисторів, i тому підібрано пари резисторів і з опором, узгодженим до третьої цифри після знаку коми. Обрано саме цю схему, так як не потрібно занадто велике значення коефіцієнту послаблення синфазного сигналу; для вирішення даної задачі повністю задовольняє коефіцієнт послаблення синфазного сигналу рівний 40 дБ, який забезпечує дана схема [6].

Активний режекторний фільтр призначений для подавлення наведень від електромережі з частотою 50 Гц [7]. Для електричної схеми активного режекторного фільтра частоти електромережі розраховано номінали елементів схеми для частоти нашої електромережі, а саме 50 Гц. Замість запропонованого у книзі зарубіжного операційного підсилювача LM110, використано вітчизняний аналог КР140УД17А. Отримані наступні значення номіналів елементів схеми:

$$
\begin{gathered}
f_{0}=\frac{1}{2 \cdot \pi \cdot R_{5} \cdot C_{2}}=50 \text { Гц } \\
R 5 \cdot C 2=0.0032 \\
R 5=R 6=2 \cdot R 8=11.8 \mathrm{MOM} \\
R 8=5.9 \mathrm{MOM} \\
C 2=C 3=\frac{C 1}{2}=270 \Pi \Phi \\
C 1=540 \Pi \Phi
\end{gathered}
$$

Електричну схему активного режекторного фільтра частоти електромережі представлено на рис. 2. 


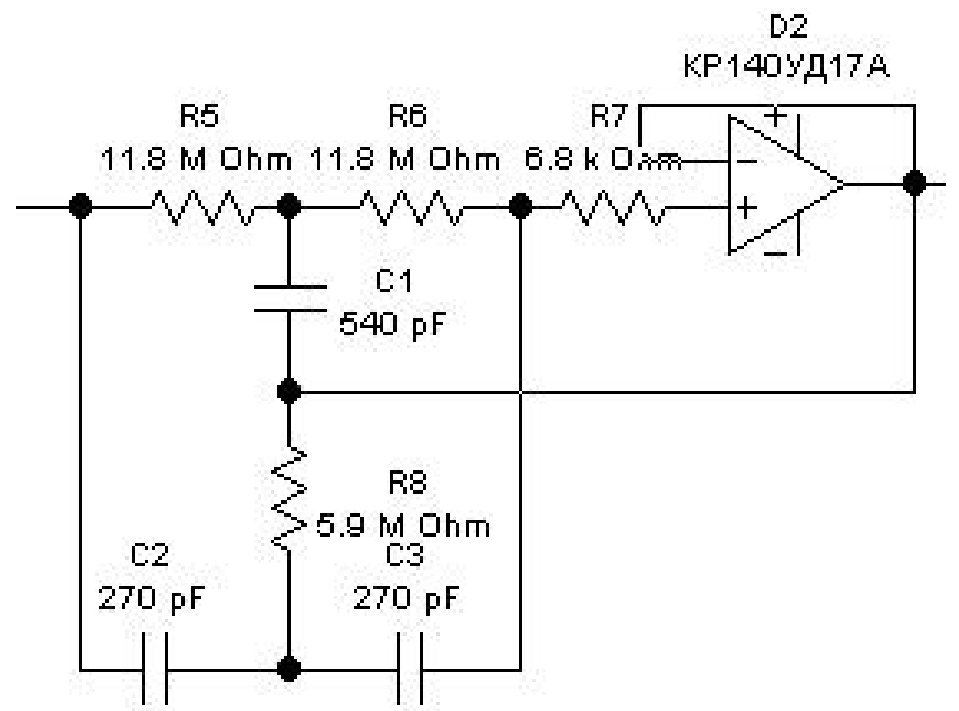

Рис. 2. Електрична схема активного режекторного фільтра частоти електромережі

Для кращої вибірковості смуги частот (250-4000 Гц) використано два активних смугових фільтра. Використано активний смуговий фільтр на базі одного операційного підсилювача КР140УД708, який об’єднує в собі схему інтегратора (фільтра нижніх частот) та диференціатора (фільтра високих частот). Смуга пропускання 250-4000 Гц. Далі приведений розрахунок елементів схеми фільтра для двох частот зрізу (250 Гц і 4кГц): Для першої частоти зрізу $f_{1}$ :

$$
\begin{aligned}
& f_{1}=4000 \text { Гц } \\
& C 5=0.01 \cdot 10^{-6} \\
& f_{1}=\frac{1}{2 \cdot \pi \cdot R 9 \cdot C 5} \\
& R 9=\frac{1}{2 \cdot \pi \cdot C 5 \cdot f_{1}} \\
& R 9=3.979 \cdot 10^{3}
\end{aligned}
$$

Для другої частоти зрізу $f_{2}$ :

$$
\begin{aligned}
& f_{2}=250 \Gamma \amalg \\
& C 7=0.01 \cdot 10^{-6} \\
& f_{2}=\frac{1}{2 \cdot \pi \cdot R 10 \cdot C 4} \\
& R 10=\frac{1}{2 \cdot \pi \cdot C 4 \cdot f_{2}} \\
& R 10=6.366 \cdot 10^{4}
\end{aligned}
$$

За результатами підібрано номінали елементів $R 9=3.9$ кОм і $R 10=62$ кОм, що повністю задовольняє частотним вимогам фільтра. Електричну схему першого активного полосового фільтра представлено на рис. 3, а.

Після випробування пристрою з одним активним смуговим фільтром вирішено додати ще один ідентичний фільтр (тобто зробити подвійну фільтрацію) задля покращення частотної характеристики (зменшення спотворень сигналу на осцилограмі пов'язаних 3 шумом та завадами отриманими на виході пристрою при використанні одного фільтру). Електричну схему другого активного смугового фільтра показано на рис. 3, б. 


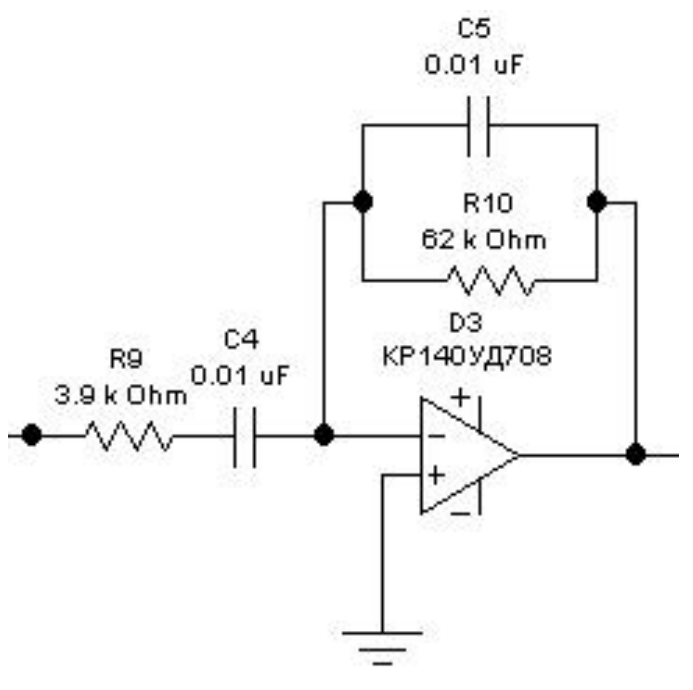

a)

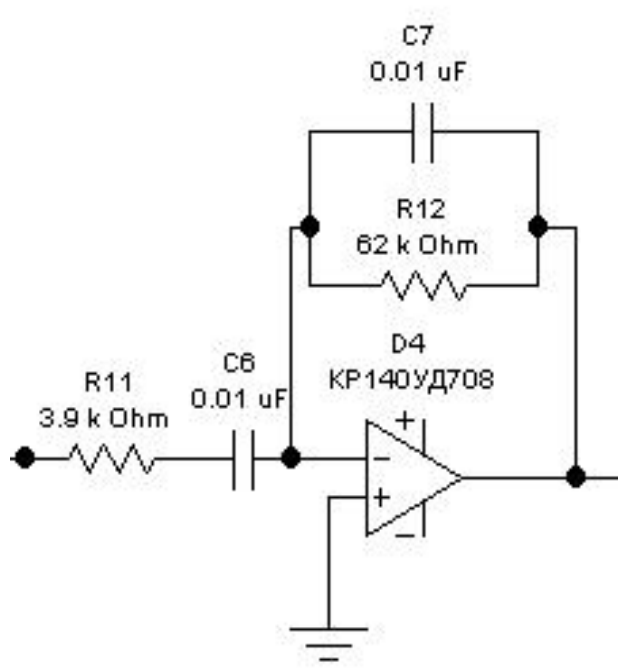

б)

Рис. 3. Електричні схеми активних смугових фільтрів: а - першого; б - другого

Останнім підсилювальним каскадом являється простий інвертуючий підсилювач. Електричну схему інвертуючого підсилювача представлено на рис. 4. За рахунок резистора R14 в схемі забезпечується глибокий негативний зворотний зв'язок. Операційний підсилювач завжди підсилює диференціальну напругу, яка прикладена безпосередньо між інвертуючим i неінвертуючим входами. При цьому коефіцієнт підсилення:

$$
K=R 14 / R 13=100
$$

Тобто інвертуючий підсилювач є останнім підсилювальним каскадом, кінцево підсилює наш відфільтрований сигнал і подає його на вихід.

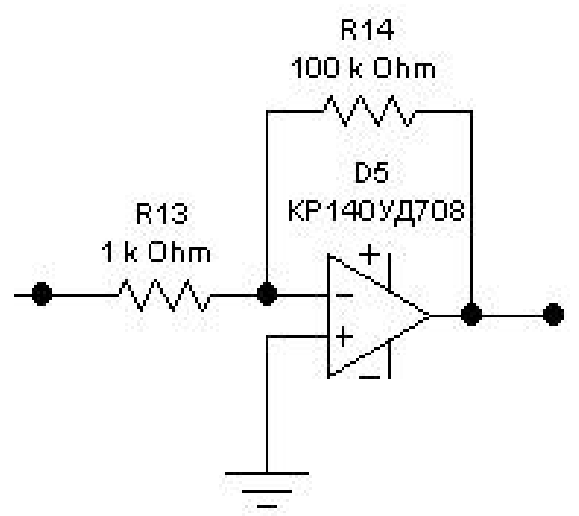

Рис. 4. Електрична схема інвертуючого підсилювача

Фільтруюча системи блока живлення являє собою елемент живлення з двома фільтрами нижніх частот (для не пропускання високочастотних завад і наводок) у вигляді RC ланцюгів, до складу яких входять резистори $R 15$ та $R 16$ з номіналом 2 кОм та електролітичні конденсатори $C 10$ та $C 11$ з номіналом 0,01 мкФ, а також пара плоских конденсаторів $C 8$ та С 9 номіналом 0.01 мкФ, що використовуються для додаткового подавлення високочастотних наводок. Електричну схему фільтруючої системи блока живлення представлено на рис. 5 . 


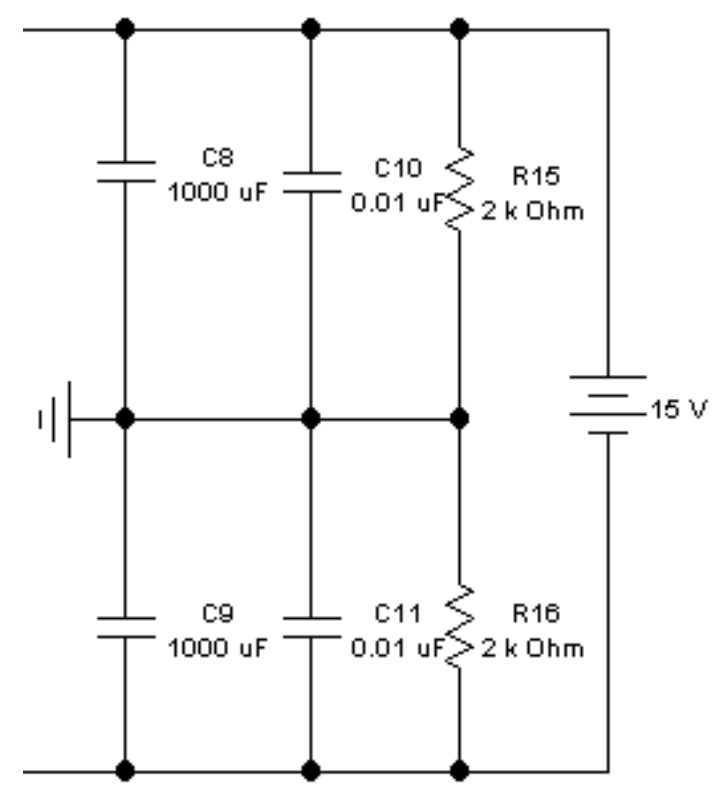

Рис. 5. Фільтруюча система блока живлення

Провід, що з'єднує акустоелелектричні перетворювачі та диференціальний підсилювач (на вході), екрановано, задля зменшення впливу наведень частоти електромережі. Отримані АЧХ і прохідна характеристика пристрою.

Висновки. Отримані рівні сигналу з акустоелектричних перетворювачів (таких як реле, динамік та дзвінковий ланцюг телефонного апарату) достатні для оцінки можливості витоку інформації по електричному каналу. Розроблено підсилювач, що може використовуватись як компактна заміна диференційного підсилювача «Піранья». Пристрій має достатній для проведення досліджень коефіцієнт підсилення і значно зменшує рівень шумів, за рахунок симетричного входу і смугових фільтрів.

\section{Література}

1. Хорошко В.А., Чекатков А.А. Методи й засоби захисту інформації / В.А. Хорошко, А.А. Чекатков. - К. : ЮHIOP, 2003. - $501 \mathrm{c}$.

2. Хорев А.А. Технические каналы утечки акустической (речевой) информации//Специальная техника. - M.: 2009. - № 5 - C. $12-26$.

3. Бузов Г.А., Калинин СВ., Кондратьев А.В. Защита от утечки информации по техническим каналам: Учебное пособие.- М.- Горячая линия-Телеком.-2005.-416 с.

4. Халяпин Д.Б. Вас подслушивают? Защищайтесь!: Защита информации. - М.: Мир безопасности, 2001. $-308 \mathrm{c}$.

5. Халяпин Д.Б. Акустоэлектрические, акустопреобразовательные каналы утечки информации и возможные способы их подавления. М.: "Мир безопасности", № 5

6. Х Хоровиц П., Хилл У. Искусство схемотехники. Изд-е 5. - М., Мир, 1998.

7. Фелпс Р. 750 практических электронных схем: справочное руководство. -М.: Мир, 1986, 584 с. 